\title{
Glucose Phosphate Isomerase Deficiency
}

National Cancer Institute

\section{Source}

National Cancer Institute. Glucose Phosphate Isomerase Deficiency. NCI Thesaurus.

Code C131643.

A rare, autosomal recessive, inherited disorder caused by mutation of the GPI gene. It is characterized by chronic, non-spherocytic hemolytic anemia. 